DOI: 10.11144/Javeriana.iyu22-1.oiav

\title{
Optimizing the Incorporation of Aloe Vera in Yacon (Smallanthus Sonchifolius Poepp. \& Endl.) through Vacuum Impregnation Using Response Surface ${ }^{1}$
}

Optimización de la incorporación de Aloe vera en yacón (Smallanthus sonchifolius Poepp. \& Endl.) mediante impregnación a vacío ${ }^{2}$

Jimy Oblitas Cruz ${ }^{3}$ Erika Rojas Gutierrez ${ }^{4}$

How to cite this article:

J. Oblitas Cruz y E. Rojas Gutiérrez, "Optimizing the Incorporation of Aloe Vera in Yacon (Smallanthus Sonchifolius Poepp. \& Endl.) through Vacuum Impregnation Using Response Surface," Ing. Univ. Eng. for Dev., vol. 22, no. 1, 2018. http://dx.doi. org/10.11144/Javeriana.iyu22-1.oiav

\footnotetext{
'Submitted on: September 26 ${ }^{\text {th }}, 2016$. Accepted on: June $21^{\text {th }}, 2017$.

${ }^{2}$ Fecha de recepción: 26 de septiembre de 2016. Fecha de aceptación: 21 de junio de 2017.

${ }^{3}$ Agro-industrial Engineer. M.Sc. in Microbiology and Food Technology, Universidad Privada del Norte, Perú. E-mail: joblitas78@gmail.com

${ }^{4}$ Food Industry Engineer. M.Sc. in Food Technology, Centro de Investigaciones e Innovaciones de la Agroindustria Peruana, Perú. E-mail: Irojas278@gmail.com
} 


\section{Abstract}

Objectives: The aim of this research was to optimize the parameters for the vacuum impregnation of Aloe vera into dried yacon (Smallanthus sonchifolius Poepp. \& Endl.) flakes. Methodology: A surface response methodology was use to evaluate the product optimization. Matrix engineering, using a vacuum impregnation technique, was employed to incorporate components with physiological activity into the pores present in the yacon flakes. An orange pulp yacon was used as the starting material and Aloe Gold Seal-Natural 200X (AGS) was used for the impregnate solution. A solution of $15 \mathrm{~g} / 100 \mathrm{ml}$ Natural Aloe 200X Gold Seal-Yacon was used to impregnate yacon samples measuring $40 \mathrm{~mm}$ in diameter and $5 \mathrm{~mm}$ thick. Results: the results show an average impregnation of $0.0721 \mathrm{~m}^{3}$ of solution $/ \mathrm{m}^{3}$ fresh fruit and an effective porosity of $18.97 \%$; the amount of aloe vera incorporated in the food matrix was between 22.5 and $54.6 \mathrm{mg} / 100 \mathrm{~g}$ sample. Optimized parameters were identified as 451.7 mbar and $22.0 \mathrm{~min}$. Conclusions: From the results, it is concluded that yacon is an excellent raw material for vacuum impregnation of Aloe vera.

\section{Keywords}

Volumetric fraction; mass fraction; impregnation solution; physiologically active components; porous structures.

\section{Resumen}

Objetivos: El objetivo de la investigación fue determinar los parámetros de impregnación a vacío con Aloe vera para obtener hojuelas de yacón deshidratadas (Smallanthus sonchifolius Poepp. \& Endl.). Metodología: se utilizó la metodología de superficie de respuesta para evaluar la optimización del producto. Para ello se utilizó yacón de color de pulpa anaranjada, y como solución de impregnación Aloe Gold Seal-Natural 200X (AGS), haciendo uso de la ingeniería de matrices que utiliza la técnica de impregnación a vacío para incorporar componentes con actividad fisiológica en la estructura de los alimentos porosos. Se empleó una disolución de $15 \mathrm{~g} / 100 \mathrm{ml}$ de Aloe Gold Seal-Natural 200X en muestras de yacón de $40 \mathrm{~mm}$ de diámetro y $5 \mathrm{~mm}$ de espesor. Resultados: se obtuvo como resultados una fracción volumétrica promedio de $0.0721 \mathrm{~m}^{3}$ solución $/ \mathrm{m}^{3}$ fruta fresca y una porosidad efectiva de $18.97 \%$; la cantidad de aloe incorporado se dio entre 22.5 y $54.6 \mathrm{mg} / 100 \mathrm{~g}$ de muestra. Al optimizar el proceso, la mayor fracción volumétrica y másica se obtuvo a 451.7 mbar y 22.0 min. Conclusiones: De los resultados obtenidos se concluye que el yacón es una materia prima en la que se puede aplicar la técnica de impregnación a vacío con Aloe vera.

\section{Palabras clave}

Fracción volumétrica; fracción másica; solución de impregnación; componentes fisiológicamente activos; estructuras porosas. 


\section{Introduction}

In recent years, numerous studies have shown that people who eat a diet rich in fruit and vegetables, with a high vitamin and antioxidant content, have a lower risk of developing diseases. The functional food market has grown significantly as a consequence of increased promotion and consumers awareness of healthy eating and lifestyle [1]. Yacon is a tuber from northern and central Andean region of South America. The growing scientific interest in yacon is due to its abundant source of fructan, fructo-oligosaccharides (FOS), instead of starch [2]. Yacon consumption is related to the promotion of human health benefits, such as hypoglycemic effects [3], [4], antioxidant activity [5]; potential chemoprevention against colon carcinogenesis [6]. On another hand, Aloe vera has enjoyed a long history of providing a myriad of health benefits, being one of the herbal remedies most frequently used throughout the world [7], [8]. The Aloe vera gel contains mainly composed of polysaccharides. Other compounds such as phenolics, organic acids, enzymes, vitamins and minerals are also present in minor quantities [9]. Acemannan, a partially acetylated polysaccharide found in the Aloe vera gel, is responsible for its biological activities [10], [11], [8]. All the conditions necessary for the production of yacon and Aloe vera are found in Peru, which makes it necessary to carry out research to develop new products or to apply new processing techniques.

In foods processing, this aim is achieved by developing actions and processes that allow the enrichment of vegetable products with desirable compounds. Within this context, vacuum impregnation (VI) has been largely used to obtain a rapid penetration of solvated compounds in plant tissues together with a homogeneous concentration profile of the solutes in the final products [12]. VI has proved to be an useful method to enrich fruit and vegetable tissue with desirable solutes (e.g. firming and antioxidant agents, flavours, cryoprotectans, vitamins, minerals, probiotics) able to stabilize and/ or improve the sensory and/ or the functional properties of food products $[13],[14],[15],[16],[17],[18]$, [19]. During VI, the vegetable porous fraction composed by the intercellular 
spaces, is filled by an external solution to a degree that depends on various factors including the applied process conditions (sub-atmospheric pressure level, process duration and temperature), the osmotic pressure and viscosity of the impregnation fluid [20], the size and shape of the samples, its effective porosity (pore size and distribution) which affects the capillary pressure of fluids within the vegetable tissue and its response to mechanical stress [18], [21], [22], [23].

Bearing in mind, the new methodologies for obtaining foods with added value, and the wide range of possibilities for capitalizing on yacon, our aim is to evaluate the response to the application of the technique of vacuum impregnation with a solution of Aloe vera in order to create products that can be produced on an industrial scale, nationally and internationally. Accordingly, the aim of this article was set out as "Establishing the parameters of vacuum impregnation with Aloe vera in order to obtain dehydrated flakes of yacon (Smallanthus sonchifolius Poepp. \& Endl.), using the response surface method".

\section{Materials and methods}

\subsection{Materials}

We used yacon (Smallanthus sonchifolius Poepp \& Endl) and a dry, pulverized aloe vera extract, devoid of aloin and with a total concentration of solids of $92 \%$ and a moisture level of $8 \%$.

\subsection{Chemicals and Reactants}

Enzyme kit for L-malic acid, which contains glycylglycine buffer $(6 \mathrm{~mL}, 1 \mathrm{M}$, $\mathrm{pH} 10.0)$ plus L-glutamate (1 M) and sodium azide $0.02 \%(w / v), N A D+(380$ $\mathrm{mg})$ plus PVP $(60 \mathrm{mg})$, suspension of glutamic-oxaloacetic transaminase $(1,25$ $\mathrm{mL}, 600 \mathrm{U} / \mathrm{mL})$, suspension of L-malate dehydrogenase $(1.25 \mathrm{~mL}, 15000 \mathrm{U} / \mathrm{mL})$ and L-malic acid standard solution $(5 \mathrm{~mL}, 0.15 \mathrm{mg} / \mathrm{mL})$, concentrated sulphuric acid, catalyst (potassium sulphate + copper sulphate), boric acid + indicator of $\mathrm{pH}$, hydrochloric acid, $0.1 \mathrm{~N}$, sulphuric acid $1.25 \%$, sodium hydroxide $1.25 \%$.

\subsection{Methods of analysis}

Proximate analysis: Moisture, proteins, fat, ash, fiber and carbohydrates (by difference), soluble solids, titratable acidity and $\mathrm{pH}$; density: AOAC method (2005); water activity, measured with AquaLab dewpoint hygrometer; color, colorimetric KONICA MINOLTA ( $\mathrm{L}^{*} \mathrm{a}$ b* scale); viscosity, measured using a rotational viscometer. 
Density of the solution: Pycnometer method at $20^{\circ} \mathrm{C}$, official method 945.06 [24] and apparent density was established in the yacon pieces using official method 942.06 [24].

Vacuum impregnation: the VI trials were carried out in an airtight stainless steel container attached to a vacuum pump. The Aloe vera solution $(15 \mathrm{~g} / 100 \mathrm{~mL})$ was shaken for a period of $15 \mathrm{~min}$. The freshly sliced samples were initially immersed in the solution and placed in the vacuum chamber in an Erlenmeyer flask. Subsequently, different pressures and timings were applied, followed by a further $10 \mathrm{~min}$ at atmospheric pressure. The development of the mass was recorded at the beginning and end of the process in order to calculate the volume fraction $(\mathrm{X})$. The parameters of impregnation $\mathrm{X}\left(\mathrm{m}^{3} \mathrm{dis} / \mathrm{m}^{3}\right.$ fresh yacon) for every impregnated sample were determined using equation 5 [25] and XHDM ( $\mathrm{kg}$ aloe $/ \mathrm{kg}$ impregnated fruit in $\mathrm{mg} / 100 \mathrm{~g}$ of yacon) by means of enzymatic analysis, for which the density of the dissolution of impregnation ( $\rho$ dis).

$$
X=\frac{M f-M i}{\rho d i s\left(\begin{array}{c}
M I \\
\rho a p m
\end{array}\right)}
$$

Where:

X: Volume fraction; Mf: final weight (after impregnation); Mi: initial weight (before impregnation); $\rho$ dis: density of the solution; $\rho$ apm: apparent density of the sample.

The effective porosity $(\varepsilon e)$ of the fruit available for the VI process was calculated on the basis of equation $2(r=$ Patm/Pvacuum), given that in the impregnation process deformation in the vacuum stage is negligible and that there is no deformation in the atmospheric pressure stage [26], [27].

$$
\varepsilon e=\frac{X}{(1-1 / r)}
$$

Where:

Ee: Effective porosity, X: Volume fraction, r: Compression ratio.

- Quantitative analysis of malic acid by means of UV spectrophotometry (AOAC Method 993.05). 
- Sensory analysis: for the sensory evaluation of the samples we used the methodology of descriptive analysis for relative quantitative categorization using an unstructured or dimensionless scale of $12 \mathrm{~cm}$ [28].

- Data analysis procedure: to determine the combination of variables and to achieve the maximum acceptance and impregnation of Aloe vera we used the design of response surface and the STATGRAPHICS Centurion program, for which an analysis of variance was carried out. For the sensory analysis, the statistical software analysis XLSTAT was used.

\section{Results and discussion}

\subsection{Establishing the effective volume fraction}

In Table 1 we present the results obtained by applying different pressures and times for impregnation, with a relaxation time of $10 \mathrm{~min}$ for all the samples. The data obtained are initial weight and final weight of the fruit subjected to impregnation with Aloe vera solutions.

With those values, the density of the impregnate solution being $1.0034 \mathrm{~g} /$ $\mathrm{cm}^{3}$ and the apparent density of the fresh yacon being $1.0121 \mathrm{~g} / \mathrm{cm}^{3}$, the volume fraction of the yacon that was impregnated $(\mathrm{X})$ is calculated, using equation 1 .

Table 1. Volume fraction of the samples impregnated with the Aloe vera solution, calculated by changes to mass (*)

\begin{tabular}{|c|c|c|c|c|}
\hline $\begin{array}{c}\text { PRESSURE } \\
\text { (mbar) }\end{array}$ & $\begin{array}{c}\text { TIME } \\
(\mathbf{m i n})\end{array}$ & $\begin{array}{c}\text { Average initial } \\
\text { mass }(\mathbf{g})\end{array}$ & $\begin{array}{c}\text { Average final } \\
\text { mass }(\mathbf{g})\end{array}$ & $\begin{array}{c}\text { Volume fraction }(X) \\
\mathbf{m}^{3} \text { solution } / \mathbf{m}^{3} \text { fresh fruit }\end{array}$ \\
\hline 275.0 & 15.0 & 6.77490 & 7.17780 & 0.06040 \\
\hline 150.0 & 10.0 & 6.76260 & 7.19373 & 0.06436 \\
\hline 400.0 & 10.0 & 6.49800 & 7.28014 & 0.12107 \\
\hline 150.0 & 20.0 & 6.69220 & 7.12590 & 0.06503 \\
\hline 400.0 & 20.0 & 6.68503 & 7.85451 & 0.17726 \\
\hline 98.2 & 15.0 & 7.02897 & 7.40073 & 0.05360 \\
\hline 451.8 & 15.0 & 6.75350 & 7.55300 & 0.11951 \\
\hline 275.0 & 7.9 & 6.66003 & 7.03453 & 0.05717 \\
\hline 275.0 & 22.1 & 6.79133 & 7.16243 & 0.05531 \\
\hline 275.0 & 15.0 & 6.73540 & 7.11740 & 0.05749 \\
\hline
\end{tabular}

(*) Average of three repetitions

Source: Authors' own creation 
As can be seen from the Table, the volume fraction data varies with regard to pressure and time. In order to calculate the average volume fraction, we took the values with data obtained after five minutes, which are plotted vs. 1-1/r; Figure 1 presents the data in graph form. Through linear regression of that data, the value of the slope corresponding to effective porosity is calculated, and where the straight line intercepts the $\mathbf{x}$ axis indicates the quantity of Aloe vera solution adhering to the fruit due to capillarity. Given that $r$ is defined as the relation between atmospheric pressure and working pressure, the $\mathbf{x}$ axis provides information about the index of pressure-gradient intensity [29].

Figure 1. Graph showing the volume fraction trend; $X$ represents the volume fraction occupied by the solution, $r$ is the relation between atmospheric pressure and working pressure

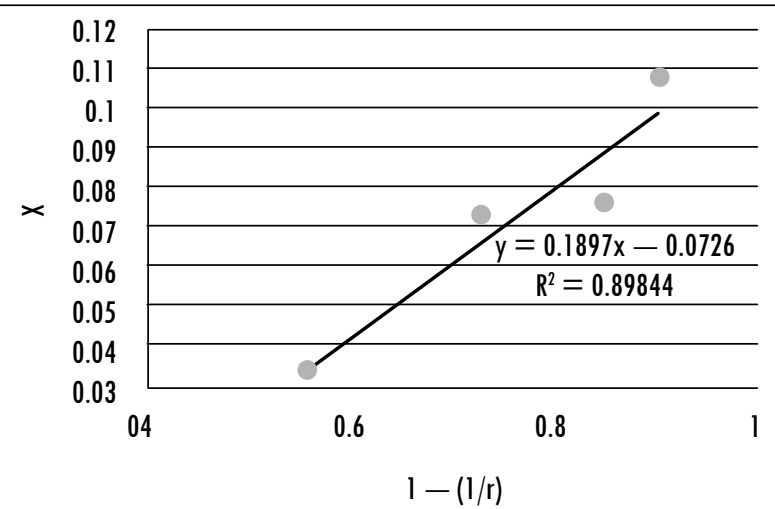

Source: Authors' own creation

As can be seen in Figure 1, the yacon sample displayed a linear increase in volume fraction, which makes it clear that its plant tissue is subject to low or almost non-existent deformation. In that regard, [30] found a similar increase for samples of apple, melon, papaya, and peach. In studies conducted on bananas, mamey, and mango they displayed a linear increase in volume fraction values up to certain limits (approximately $400 \mathrm{mbar}$ ), after which the level of impregnation decreased.

The authors hypothesized that these operating conditions could have produced a high level of deformation (i.e. of compression) in the plant tissue, which reduced the vacuum phase available for the penetration of liquids. The conclusion was that these fruits suffer high levels of deformation when they are subjected to VI treatments in particular operative conditions. The authors stressed the importance of internal variables, such as the number and diameter of pores, 
the mechanical properties of the solid matrix as well as the spatial distribution and characteristics of the cells, and also the type of fluid (liquid or gas) present in the intercellular space, which have to be taken into consideration in order to make precise adjustments to vacuum impregnation treatments.

Linear regression of the experimental data shows that the volume fraction (intercept value) is an average of 0.0726 , that is to say almost $0.1 \mathrm{~m}^{3}$ solution/ $\mathrm{m}^{3}$ fresh fruit. In apple products enriched with calcium and iron, [31] obtained a volume fraction of 0.19 , and states that the volume fraction of liquid incorporated decreases when the concentration of calcium and iron salts in the impregnation liquid increases, and that the lower impregnation values match greater contraction in the sample. In his research into the impregnation of plant tissue with probiotic microorganisms, [31] also mentions that in apple impregnated with S. cerevisiae in apple juice he found that the volume fraction value was 0.18 , while with apple impregnated with $\mathrm{L}$. casei in apple juice it was 0.19 .

\section{Establishing effective porosity}

Effective porosity is established with linear regression of the volume fraction (X) against 1-1/r, (Figure 1), where the slope is the effective porosity [33].

$$
\mathrm{Y}=0.1897 \mathrm{x}-0.0726
$$

The slope is 0.1897 , and therefore effective porosity is $18.97 \%$, which shows that yacon can be impregnated with this percentage of its volume, [32] reported at $23.6 \%$ in apple, and this is possibly due to differences in the intracellular spaces in the yacon. This is confirmed by [33], who state that the presence of pores in foods can be attributed to many factors, one of which is the existence of the intercellular spaces that are found in the parenchymatous tissue of fruits. The pores are not homogeneous in size. AI samples unimpregnated pineapple presented values of porosity lower than vacuum impregnated samples, which can be easily explained considering that vacuum application modify the porous structure, causing its expansion [34].

In general, the higher the porosity, the higher the level of impregnation [29], [33] showed that the levels of impregnation were directly correlated with the porosity values of the vegetables. However, while the porosity value is an indicator, it is not sufficient to characterize foods completely or to predict their behavior during vacuum impregnation. 


\subsection{Quantitative assessment of malic acid}

Table 2 shows the values of malic acid (mass fraction X MHD) that were established:

Table 2. Quantitative assessment of malic acid (*)

\begin{tabular}{|c|c|c|}
\hline $\begin{array}{c}\text { PRESSURE } \\
\text { (mbar) }\end{array}$ & $\begin{array}{c}\text { TIME } \\
(\mathbf{m i n})\end{array}$ & $\begin{array}{c}\text { Mass Fraction } \\
\text { (X MHD) mg/100g of yacon }\end{array}$ \\
\hline 275.0 & 15.0 & 22.5086 \\
\hline 150.0 & 10.0 & 30.0115 \\
\hline 400.0 & 10.0 & 31.6371 \\
\hline 150.0 & 20.0 & 26.2979 \\
\hline 400.0 & 20.0 & 32.7804 \\
\hline 98.2 & 15.0 & 24.3954 \\
\hline 451.8 & 15.0 & 54.6339 \\
\hline 275.0 & 7.9 & 32.6489 \\
\hline 275.0 & 22.1 & 27.3170 \\
\hline 275.0 & 15.0 & 33.5254 \\
\hline
\end{tabular}

(*) Average of three repetitions

Source: Authors' own creation

The only organic acid contained in the gel of fresh Aloe leaf is malic acid. Aloe is a CAM-type plant (Crassulacean Acidic Metabolism plants), and these plants differ from other plants in the vegetable kingdom by not developing photosynthesis. They open their stomata at night, thereby avoiding transpiration during periods of great daytime heat, and convert carbon dioxide to malic acid. The following day, with their stomata closed, they convert the malic acid into sugars.

The vacuolar accumulation of $\mathrm{CO}_{2}$ from organic acids, specifically malic acid, makes it possible to quantify its content and in this way to calculate the total presence of Aloe. The malic acid content in the gel of fresh Aloe is, approximately, between $409-656 \mu \mathrm{mol} / \mathrm{g}$ of dry weight or $5.48-8.80 \mathrm{~g}$ malic acid/100 g aloe [35].

The results we obtained made it possible to quantify the amount of Aloe incorporated: it was between 22.5086 and $54.6339 \mathrm{mg} / 100 \mathrm{~g}$ of the yacon. The final Aloe vera content is similar to that offered in capsule format, in capsules of $50 \mathrm{mg}$ to $1 \mathrm{~g}$. 
According to [36], VI makes it possible to attain high CFA levels: for each 100 $\mathrm{g}$ of fresh mushroom at a vacuum pressure of $110 \mathrm{mbar}$ over a period of $5 \mathrm{~min}$ $43.0 \pm 2.33 \mathrm{mg} \operatorname{VitC}(71.7 \pm 3.9 \% \mathrm{VDR}), 30.91 \pm 6.91 \mathrm{mg}$; VitE (103.0 $23.0 \%$ VDR), $4.23 \pm 0.03 \mathrm{mg} \mathrm{Zn}(28.2 \pm 0.2 \%$ VDR) were obtained, and the calcium contributed to obtaining an acceptable texture with elastic characteristics and good resistance to deformation with levels of $4.58 \pm 0.06 \mathrm{mg}$ of $\mathrm{Ca}$.

\subsection{Effect of the impregnation process}

In order to analyze better the nature of the changes to the product during the different operations it undergoes, the behavior of the yacon samples during VI with the Aloe vera solution was studied.

As regards the effect of applying high vacuum pressures for prolonged processing times, a direct effect was observed, namely, there was an increase in volume fraction (X) and mass fraction (X mhd) as this factor (pressure) increased. Figure 2 shows the effects of each independent variable on volume fraction (X) and Figure 3 shows the effects on mass fraction (X mhd). In those figures, the tendency for solute gains in the fruit as a function of time and vacuum pressure can be observed.

Figure 2. Diagram of main effects for volume fraction

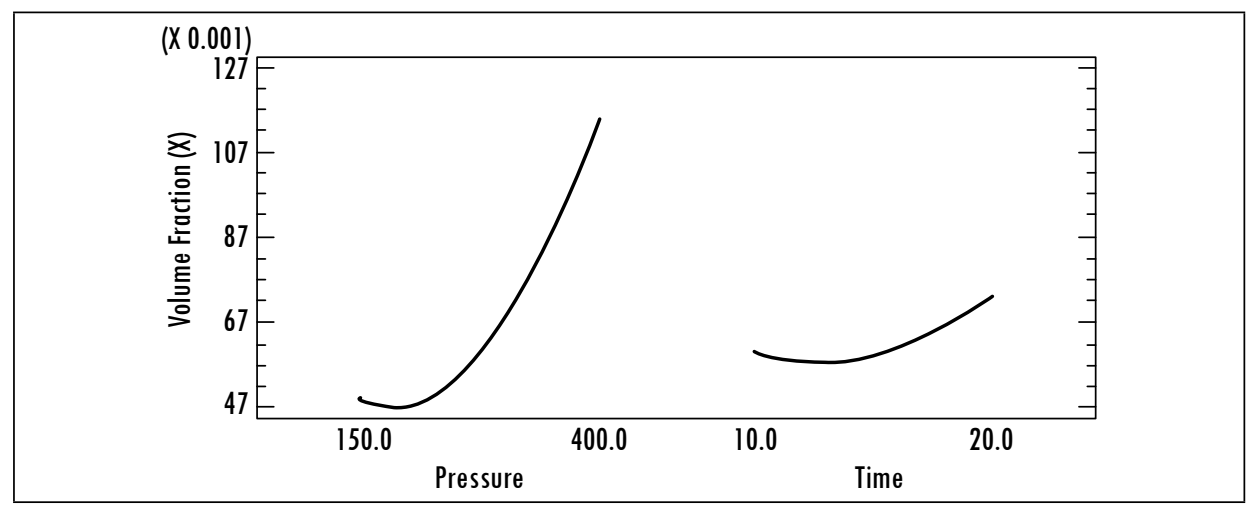

Source: Authors' own creation

Among the external variables, vacuum pressure can be considered the most important, given that it represents the force that produces the pressure gradient between the vacuum phase of foods and the atmosphere surrounding the external liquid. The vacuum level is generally linked to an increase in the level of impregnation (X) as a result of a greater release of the plant's own liquids and 
gases, together with a higher HDM and DRP. [22], studied the effect of vacuum pressure between 135 and 674 mbar on the volume of pores impregnated in an isotonic solution of various fruits. For one group of these fruits they observed a greater impregnation in line with an increase in vacuum pressure, but for the other group the values of $\mathrm{X}$ increased with an increase in the vacuum level up to a maximum, after which impregnation was slightly reduced.

Figure 3. Diagram of main effects for mass fraction

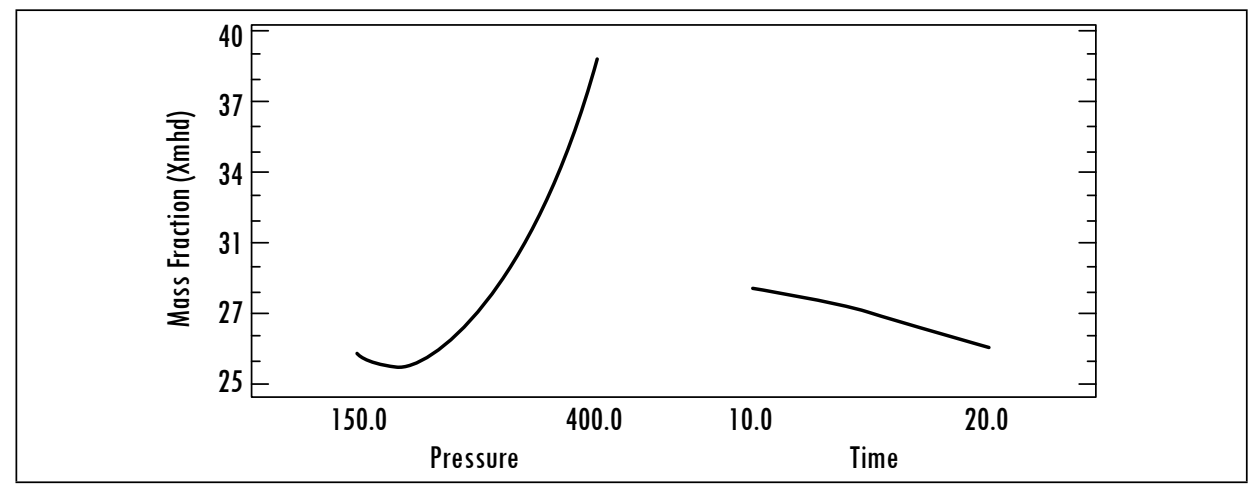

Source: Authors' own creation

Figure 4 shows the estimated response surface for the effect of these relevant process variables on volume fraction $(\mathrm{X})$. Figure 5 shows the estimated response surface for the effect of these relevant process variables on mass fraction ( $\mathrm{X}$ mhd).

Figure 4. Response surface for volume fraction according to Time and Pressure

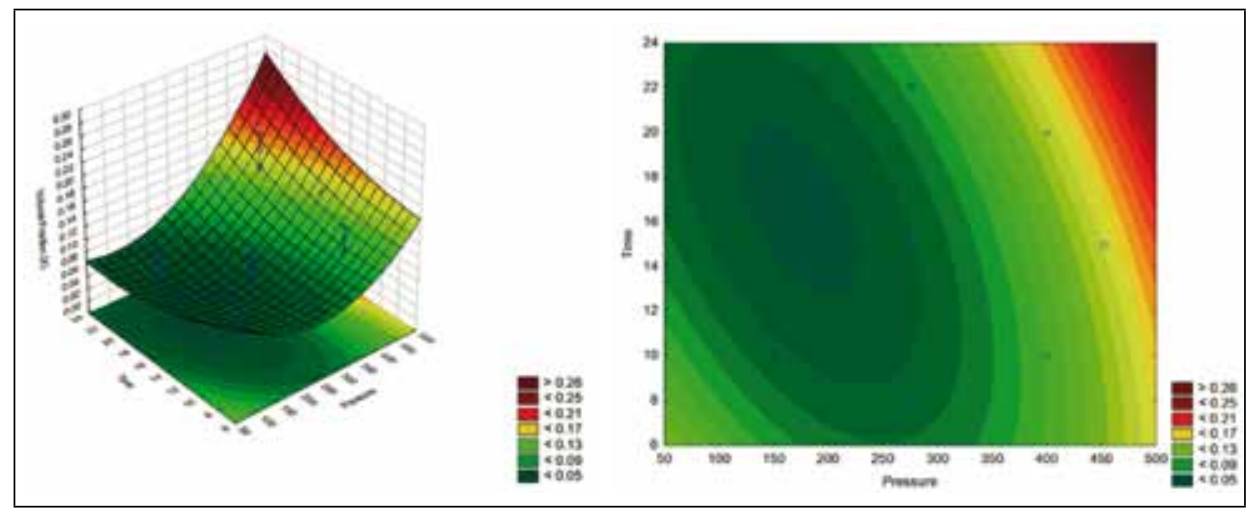

Source: Authors' own creation 
The equation that describes the estimated response surface for volume fraction with the relevant process variables, plotted in Figure 4, is shown in the following equation.

Volume fraction $(\mathrm{X})=0.235726-0.000869622 *$ Pressure $-0.0137901 *$ Time $+0.0000014521 *$ Pressure $^{\wedge}+0.000022208 *$ Pressure*Time + $0.000301294 *$ Time $^{\wedge} 2$

Figure 5. Response surface for mass fraction according to Time and Pressure

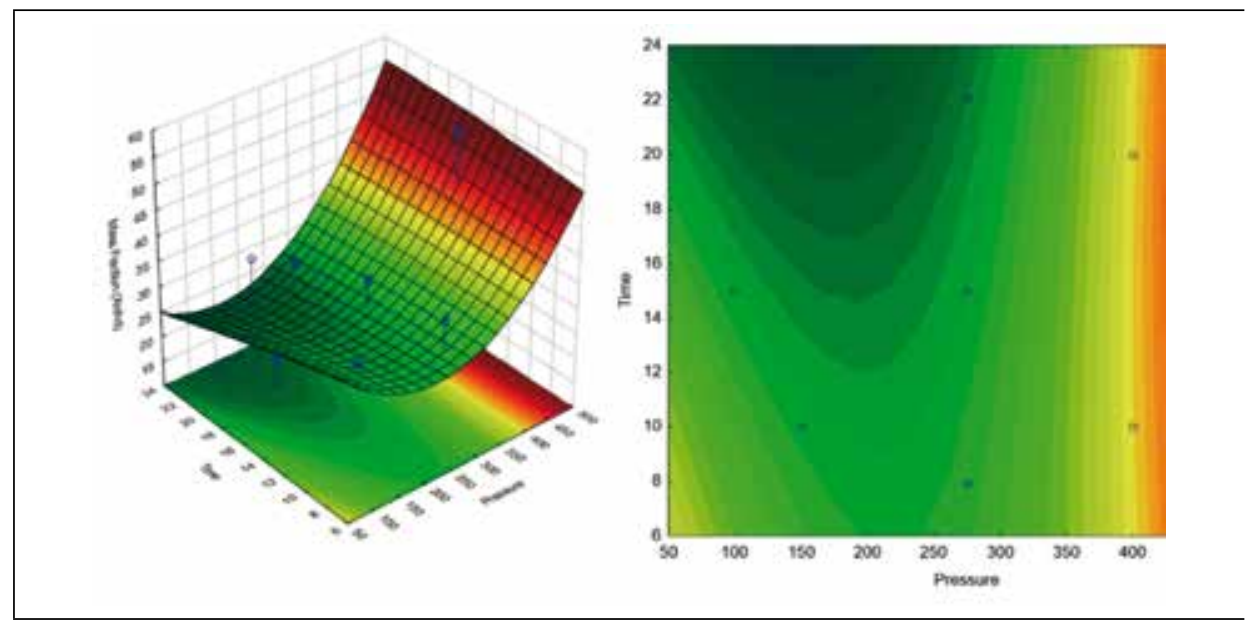

Source: Authors' own creation

The equation that describes the estimated response surface for volume fraction with the relevant process variables, illustrated in Figure 5, is shown in the following equation.

Mass fraction $(\mathrm{X}$ mhd $)=46.7017-0.140438 *$ Pressure $-0.596479 *$ Time $+0.000294853 *$ Pressure` $^{\wedge}+0.00194273 *$ Pressure*Time $0.00635141 *$ Time $^{\wedge} 2$

These results corroborate the premise that vacuum gauge pressure is the driving force in the process of vacuum impregnation, given that it was the most relevant effect. By optimizing (maximizing) the process, the highest volume fraction and mass fraction that is obtained is 46.5476 , and it is obtained using a pressure of $451.777 \mathrm{mbar}$ and a time of $22.0711 \mathrm{~min}$.

The vacuum period and relaxation times represent two important variables that affect the results of applying VI. When a short vacuum period is applied, the elimination of gases from the pores is not completed, and thus the gas residues could have impeded penetration by the solution. When the vacuum period 
increases, the gases are completely eliminated. An increase in solids gain can be observed up to a relaxation time of $30 \mathrm{~min}$, after which the values of solids gained are roughly constant [30]. Those authors put forward the hypothesis that $30 \mathrm{~min}$ is the time necessary to reach a situation of equilibrium, after which no difference in solids gain is to be observed. The effect that high vacuum pressures have on parenchymatous cell deformation, together with the difference in size between the molecules of the solute and of water, makes diffusion of the solute through the cell membrane difficult [26].

Such is the case mentioned in [30], where banana, mamey and mango displayed a linear increase in the values of $\mathrm{X}$ up to certain limits (approximately $400 \mathrm{mbar})$, after which the level of impregnation decreased.

\subsection{Effect of the process on luminance $(L)$}

Color is a highly important characteristic in the physical assessment of the quality of foods and can have a negative effect on the presentation of the product.

In the data evaluated, three effects have a p-value less than 0.05 , showing that they are significantly different from zero with a $95.0 \%$ confidence level. The most important effect is pressure, as shown in Figure 6.

Figure 6. Graph of main effects for $L$

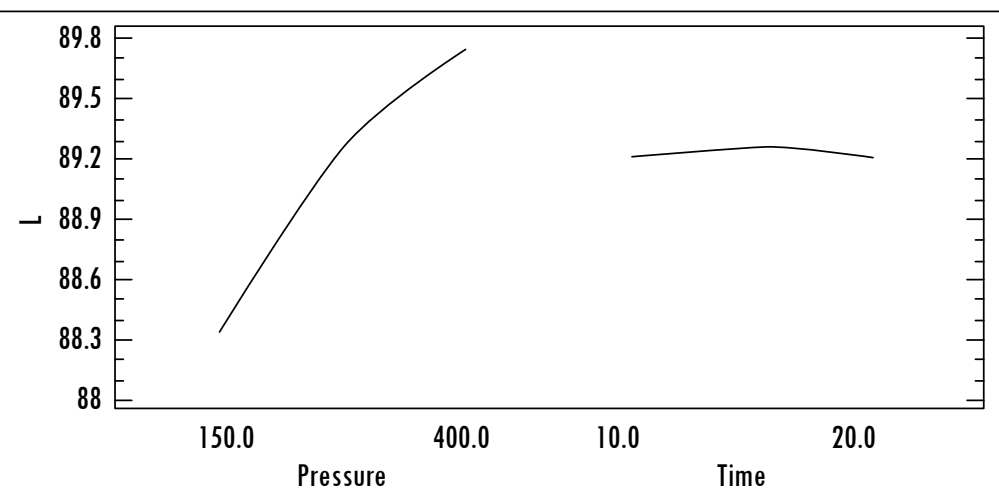

Source: Authors' own creation

Objective evaluation of color was carried out on the basis of changes to luminance $(\mathrm{L})$, it being noted that the highest value obtained after the impregnation process is (89.89), achieved with a pressure of $98.22 \mathrm{mbar}$ for a time of $7.93 \mathrm{~min}$. 
According to [37], the change in color is due to the fact that the gas-fluid exchange in the process of impregnation homogenizes the refractive index of the sample, which increases the transparency of the product.

In yacon, the luminance is seen to rise as the pressure increases; that is to say, pressure tends to increase transparency. This may also be due to the use of Aloe vera, because of its chemical composition and the amount of phenolic compounds that inactivate the polyphenol oxidase that is responsible for enzymatic browning in many fruits. Figure 7 presents the response surface for the $L^{*}$ function of time and pressure.

Figure 7. Response surface for the $L$ function of Time and Pressure

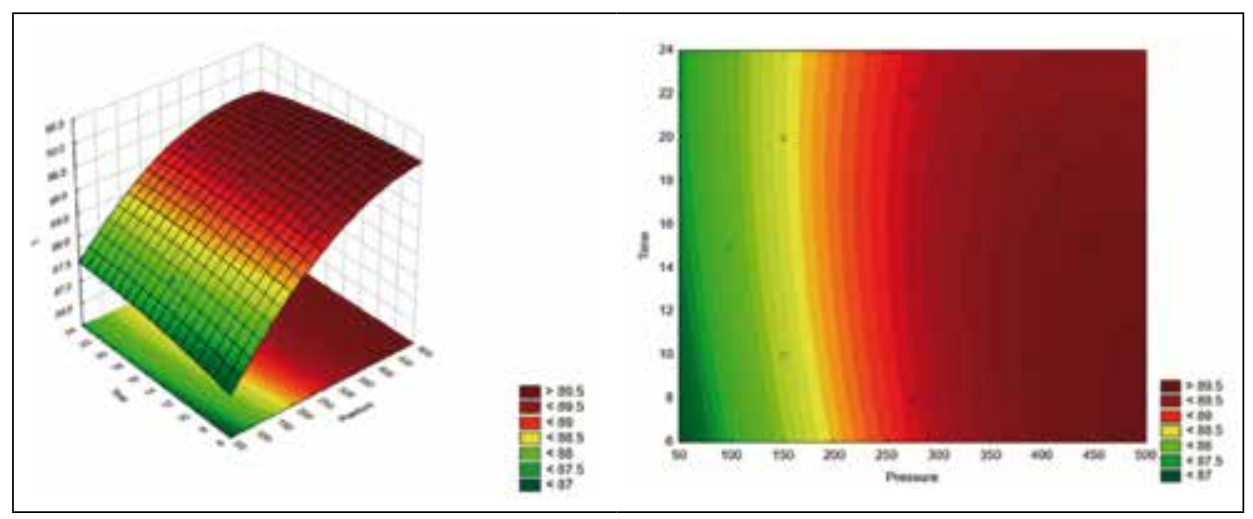

Source: Authors' own creation

The equation that describes the estimated response surface for $\mathrm{L}^{*}$ with the relevant process variables, plotted in Figure 7, is shown in the following equation.

$\mathrm{L}=85.8209+0.0149256 *$ Pressure $+0.0790348 *$ Time $-0.0000136 *$ Pressure $^{\wedge} 2-0.00012 *$ Pressure*Time $-0.00149998 *$ Time $^{\wedge} 2$

\subsection{Sensory analysis}

Table 3 presents the results of an ANOVA test conducted for color and taste. As can be seen, the sensory evaluation of taste was significant. The result is due to the faint presence of acidity in the impregnated dehydrated yacon, given that the Aloe vera solution had a $\mathrm{pH}$ of 3.77 , which differentiates it from an unimpregnated sample of dehydrated yacon. It is worth adding that the impregnated sample was not unpleasant for the evaluator, as expressed in the comments on the sensory evaluation chart used. 
The replacements of inter- and intra-cellular gas with the impregnation solution, which presents a viscosity higher than that of the internal gas, can positively influence the product consistency and turgidity [38] As regards color, the sensory evaluation showed non-significant results; color is one of the most important quality parameters in dehydrated products. Changes in color are due to the concentration of pigments or their degradation. By removing the air from fruit pores and introducing specific solutes, vacuum impregnation can help to prevent browning [16]

Table 3. ANOVA Summary

\begin{tabular}{|l|c|c|}
\hline \multicolumn{1}{|c|}{ Descriptors } & F & Pr > F \\
\hline Color & 1.707 & 0.101 \\
\hline Taste & 2.045 & 0.045 \\
\hline \multicolumn{2}{|l}{ The values in bold correspond to the descriptors eliminated. } \\
\hline
\end{tabular}

Source: Authors' own creation

\subsection{Characterization of the final product}

Table 4 presents the results of the chemicophysical analysis of the yacon impregnated with Aloe vera after dehydration. The sample analyzed was the one that produced significant results in the impregnation trials as regards volume and mass fraction, namely the sample subjected to a pressure of $451.8 \mathrm{mbar}$ and a time of $22 \mathrm{~min}$.

Table 4. Chemicophysical analysis of the yacon impregnated with Aloe vera $\left(^{*}\right)$

\begin{tabular}{|l|c|}
\hline \multicolumn{1}{|c|}{ Components } & Percentage \\
\hline Moisture content & 16.39 \\
\hline Dry matter & 83.61 \\
\hline Ash & 2.07 \\
\hline Protein & 2.01 \\
\hline Crude fiber & 2.68 \\
\hline Fat & 0.13 \\
\hline NFE (Carbohydrates) & 76.72 \\
\hline pH & 5.50 \\
\hline Acidity (exp. Citric acid) & 0.45 \\
\hline Soluble solids ( ${ }^{\circ}$ Brix) & 13.8 \\
\hline
\end{tabular}

(*) Average result of three repetitions

Source: Authors' own creation 
According to the data obtained, it is worth noting the low moisture content (16.39\%), which gives the product a certain degree of stability; when the flakes came out of the dryer, they had a semi-crunchy texture, which could easily be quickly lost if they are not packaged immediately. Proximate analysis gave results of: dry matter, 83.61\%; ash, 2.07\%; protein, $2.01 \%$; crude fiber, $2.68 \%$; fat, $0.13 \%$; carbohydrates, $76.72 \%$. What stands out is the high carbohydrate content of yacon. Of total carbohydrates, $50 \%$ to $70 \%$ are fructooligosaccharides (FOS), while the remaining carbohydrates comprise sucrose, fructose, and glucose [39]. The substitution with the Aloe vera solution (rich in carbohydrates) of the yacon pores typical of the gel of the parenchymatous tissue of Aloe vera also contributes to the carbohydrate content of the final product; according to the literature, monosaccharides and polysaccharides such as glucomannan are present in Aloe vera. The polysaccharides of Aloe vera have been proven to contribute to pharmacological activity in stimulating cell proliferation and to biological activities such as anti-inflammatory, antiviral, inmunomodulatory, anti-ulcerative, disinfectant, healing and antioxidant activities [40].

\section{Conclusions}

An average volume fraction of $0.0721 \mathrm{~m}^{3}$ solution $/ \mathrm{m}^{3}$ fresh fruit and an effective porosity of $18.97 \%$ were obtained; quantification of the amount of Aloe incorporated varied between 22.5086 and $54.6339 \mathrm{mg} / 100 \mathrm{~g}$ of the sample.

Response Surface Methodology (RSM) allowed the optimization of mass fraction and volume fraction at a pressure of $451.777 \mathrm{mbar}$ and a time of 22.0711 minutes.

The sensory evaluation of the 10 semi-trained panel members showed that the p-value for color was 0.101 and for taste it was 0.045 , which shows that they do not find a significant difference for the color $(\mathrm{p}>0.05)$, while taste is significant for this analysis $(\mathrm{p}<0.05)$.

\section{References}

[1] L. Day, R.B. Seymour, K.F. Pitts, I. Konczak, and L. Lundin, "Incorporation of functional ingredients into foods," Trends Food Sci. Tech. vol. 20, no. 9, pp. 388-395. Sep. 2009. https://doi.org/10.1016/j.tifs.2008 .05.002

[2] Q. Shi, Y. Zheng, and Y. Zhao, "Thermal transition and state diagram of yacon dried by combined heat pump and microwave method,"J.Therm. Anal. Calorim., vol. 119, no. 1, pp. 727-735. Jan. 2015. https://doi.org/10.1007/s10973-014-4198-0 
[3] H. Satoh, ;- M. T. A. Nguyen, A. Kudoh, and T. Watanabe, "Yacon diet (Smallanthus sonchifolius, Asteraceae) improves hepatic insulin resistance via reducing Trb3 expression in Zucker fa/fa rats," Nutr. Diabetes, vol. 3, no. 5, pp. 1-6. May 2013. https://doi. org/10.1038/nutd.2013.11

[4] C. Serra-Barcellona, et al., "Smallanthus macroscyphus: a new source of antidiabetic compounds," Chem.-Biol Interac., vol. 209, pp. 35-47. Feb 2014. https://doi.org/10.1016/j. cbi.2013.11.015

[5] S. Sousa, et al., "Antioxidant properties of sterilized yacon (Smallanthus sonchifolius) tuber flour," Food Chem., vol. 188, pp. 504-509. Dec. 2015. https://doi.org/10.1016/j. foodchem.2015.04.047

[6] N. A. Moura, et al., "Protective effects of yacon (Smallanthus sonchifolius) intake on experimental colon carcinogenesis," Food Chem. Toxicol., vol. 50, no. 8, pp. 2902- 2910. Aug. 2012. https://doi.org/10.1016/j.fct.2012.05.006

[7] X. Guo, and N. Mei, "Aloe vera: A review of toxicity and adverse clinical effects," J. Environ. Sci. Health. C. Environ. Carcinog. Etocoxicol Rev., vol. 34, no. 2 pp. 77-96. Apr. 2016. https://doi.org/10.1080/10590501.2016.1166826

[8] R. Pothuraju, R. K. Sharma, S. K. Onteru, S. Singh, and S. A. Hussain "Hypoglycemic and hypolipidemic effects of Aloe vera extract preparations: A review," Phytother. Res., vol. 30, no. 2, pp. 200-207. Feb. 2016. doi: 10.1002/ptr.5532.

[9] A. Femenia, E. S. Sánchez, S. Simal, and C. Rosselló, "Compositional features of polysaccharides from Aloe vera (Aloe barbadensis Miller) plant tissues". Carb. Pol., vol. 39, no. 2, pp. 109-117. Jun. 1999. https://doi.org/10.1016/S0144-8617(98)00163-5

[10] J. Chokboribal, W. Tachaboonyakiat, P. Sangvanich, V. Ruangpornvisuti, S. Jettanacheawchankit, and $\mathrm{P}$. Thunyakitpisal, "Deacetylation affects the physical properties and bioactivity of acemannan, an extracted polysaccharide from Aloe vera," Carb. Pol., vol. 133, pp. 556-566. Nov. 2015. https://doi.org/10.1016/j.carbpol.2015.07.039

[11] S. Kumar, and A. B. Tiku, "Immunomodulatory potential of acemannan (polysaccharide from Aloe vera) against radiation induced mortality in Swiss albino mice," Food Agr. Immunol., vol. 27, no. 1, pp. 72-86. 2016. https://doi.org/10.1080/09540105.2015.1 079594

[12] J. Moreno, et al., "Effect of pulsed-vacuum and ohmic heating on the osmodehydration kinetics, physical properties and microstructure of apples (cv. Granny Smith)," Innov. Food Sci. Emerg. Technol., vol. 12, no. 4, pp. 562-568. Oct. 2011. https://doi.org/10.1016/j. ifset.2011.06.011

[13] E. Radziejewska-Kubzdela, R. Biegańska-Marecik, and M. Kidoń, "Applicability of vacuum impregnation to modify physico-chemical, sensory and nutritive characteristics of plant origin products-a review," Int. J. Mol. Sci., vol. 15, no. 9, pp. 16577-16610. 2014. doi:10.3390/ijms150916577 
[14] A. Derossi, T. De Pilli, M. P. La Penna, and C. Severini, "pH reduction and vegetable tissue structure changes of zucchini slices during pulsed vacuum acidification," LWT Food Sci. Technol., vol. 44, no. 9, pp. 1901-1907. Nov. 2011. https://doi.org/10.1016/j. lwt.2011.01.011

[15] N. Betoret, et al., "Development of probiotic-enriched dried fruits by vacuum impregnation,” J. Food Eng., vol. 56, no. 2-3, pp. 273-277. Feb. 2003. https://doi.org/10.1016/ S0260-8774(02)00268-6

[16] K. Hironaka, et al., "Ascorbic acid enrichment of whole potato tuber by vacuum-impregnation”. Food Chem., vol. 127, no. 3, pp. 1114-1118. Aug. 2011. https://doi.org/10.1016/j. foodchem.2011.01.111

[17] M. Jeon, and Y. Zhao, "Honey in combination with vacuum impregnation to prevent enzymatic browning of fresh-cut apples," Int. J. Food Sci. Nutr., vol. 56, no. 3, pp. 165176. 2005. https://doi.org/10.1080/09637480500131053

[18] B. Schulze, S. Peth, E. M. Hubbermann, and K. Schwarz, "The influence of vacuum impregnation on the fortification of apple parenchyma with quercetin derivatives in combination with pore structures X-ray analysis," J. Food Eng., vol. 109, no. 3, pp. 380387. Apr. 2012. https://doi.org/10.1016/j.jfoodeng.2011.11.015

[19] P. Comandini, G. Blanda, H. Mújica Paz, A. Valdez Fragoso, and T. Gallina Toschi, "Impregnation techniques for aroma enrichment of apple sticks: a preliminary study," Food Bioprocess Technol., vol. 3, no. 6, pp. 861-866. Dec. 2010. https://doi.org/10.1007/ s11947-010-0385-6

[20] A. Guillemin, P. Degraeve, C. Noël, and R. Saurel, "Influence of impregnation solution viscosity and osmolarity on solute uptake during vacuum impregnation of apple cubes (var. Granny Smith)," J. Food Eng., vol. 86, no. 4, pp. 475-483. Jun. 2008. https://doi. org/10.1016/j.jfoodeng.2007.10.023

[21] P. Fito, A. Andrés, A. Chiralt, and P. Pardo, "Coupling of hydrodynamic mechanism and deformation-relaxation phenomena during vacuum treatments in solid porous food-liquid systems," J. Food Eng., vol. 27, no. 3, pp. 229-240. 1996. https://doi.org/10.1016/02608774(95)00005-4

[22] H. Mújica-Paz, A. Valdez-Fragoso, A. López-Malo, E. Palou, and J. Welti-Chanes, "Impregnation properties of some fruits at vacuum pressure," J. Food Eng., vol. 56, no. 4, pp. 307-314. Mar. 2003. https://doi.org/10.1016/S0260-8774(02)00155-3

[23] H. Mújica-Paz, A. Valdez-Fragoso, A. López-Malo, E. Palou, and J. Welti-Chanes, "Impregnation and osmotic dehydration of some fruits: effect of the vacuum pressure and syrup concentration," J. Food Eng., vol. 57, no. 4, pp. 305-314. May. 2003. https://doi. org/10.1016/S0260-8774(02)00344-8

[24] AOAC, Official Methods of Analysis of AOAC International Agricultural Chemists, 16th ed., vol: 1-2, 2005. 
[25] M. Cortés, F. Guardiola, and R. Pacheco, "Aplicación de la ingeniería de matrices en la fortificación de mango (var. Tommy Atkins) con calico," Dyna, vol. 74, no. 153, pp. 1926. Nov. 2007.

[26] P. Fito, "Modelling of vacuum osmotic dehydration of food,".J. Food Eng., vol. 22, no. 1-4, pp. 313-328. 1994. https://doi.org/10.1016/0260-8774(94)90037-X

[27] P. Fito, and R. Pastor, "Non-diffusional mechanisms occurring during vacuum osmotic dehydration,".J. Food Eng., vol. 21, no. 4, pp. 513-519. 1994. https://doi.org/10.1016/02608774(94)90070-1

[28] A. Anzaldúa La evaluación de los alimentos en la teoría y en la práctica. Zaragoza: Acribia. Ballús C: Psicobiología. Herder: Barcelona. 1994

[29] T. Derossi, T. De Pilli, and C. Severini, The Application of Vacuum Impregnation Techniques in Food Industry" in Scientific, Health and Social Aspects of the Food Industry, $2^{\text {nd }}$ ed. Buenos Aires: Ed. Univ. de Bs As, 2012.

[30] H. Mújica, A. Valdez, A. López, E. Pallou, J. Welti, "Impregnation properties of some fruits at vacuum pressure." J. Food Eng., vol 56, pp. 307-314. 2002.

[31] P. Fito, "Complejidad y funcionalidad de los sistemas de ingeniería de alimentos: La Ingeniería de matrices en el desarrollo de alimentos frescos funcionales ('Complexity and functionality of food engineering systems: matrix engineering in the development of fresh functional foods'); Departamento de Tecnología de alimentos, Universidad Politécnica de Valencia, Spain. 2003

[32] A. Gilibert, "Desarrollo de alimentos funcionales. Incorporación de calcio y zinc por procesos de impregnación a vacío de jarabes de sacarosa," MSc thesis, Univ. de las Américas, Puebla, Mexico, 2002.

[33] P. Fito, A. Andrés, A. Chiralt and P. Pardo, "Coupling of hydrodynamic mechanism and deformation-relaxation phenomena during vacuum treatments in solid porous food-liquid systems," J. Food Eng., vol. 27, pp. 229-240. 1996.

[34] M. Mateus, et al., "Vacuum impregnation and drying of calcium-fortified pineapple snacks,” LWT-Food Sci. Technol., vol. 72, pp. 501-509. 2016. https://doi.org/10.1016/j. lwt.2016.05.016

[35] A. Paez, M. G. Gebre, M. E. González, and T. J. Tschaplinski, "Growth, soluble carbohydrates, and aloin concentration of Aloe vera plants exposed to three irradiance levels," Environ. Exp. Bot., vol. 44, no. 2, pp. 133-139. Oct. 2000.

[36] M. P. Ruiz, "Aplicación de la ingeniería de matrices en el desarrollo de hongos comestibles (Pleorotus Ostreatus) Mínimamente procesados, fortificados con vitaminas C, E y minerales calcio y zinc,” MSc Thesis, Fac. Ciencias Agropecuarias, UNAL, Medellín, 2009.

[37] P. Fito, et al., "Vacuum impregnation for development of new dehydrated products," J. Food Eng., vol. 49, no. 4, pp. 297-302. Sep. 2001. https://doi.org/10.1016/S02608774(00)00226-0 
[38] L. Neri, et al., "Use of vacuum impregnation for the production of high quality fresh-like apple products," J. Food Eng., vol. 179, pp. 98-108. Jun. 2016. https://doi.org/10.1016/j. jfoodeng.2016.02.002

[39] J. Seminario, M- Valderrama, and I. Manrique, El Yacón: fundamentos para el aprovechamiento de un recurso promisorio. Lima, Perú: Centro Internal. de la Papa (CIP), Univ. Nal. de Cajamarca, Agencia Suiza para el Desarrollo y la Coop. (COSUDE), 2003, 60 pp.

[40] J. Yimei, Z. Guodong, J. Jicheng, "Preliminary evaluation: the effects of Aloe ferox Miller and Aloe arborescens Miller on wound healing,"J. Ethnopharmacol., vol. 120, no.2, pp. 181-189. Nov. 2008. doi: 10.1016/j.jep.2008.08.008 